\title{
Four New Records of Eriophyids and Associated Phytoseiids from Egypt
}

\author{
A. S. Elhalawany*; A. S. Sanad* and X. F. Xue ${ }^{* *}$ \\ "Plant Prot. Res. Inst., Agri. Res. Center, Dokki, Giza, Egypt. \\ ***Department of Entomology, Nanjing Agricultural University, Nanjing, Jiangsu, P. R. China.
}

\begin{abstract}
The present study reports four new records of eriophyid mites collected from Egypt during 2012 to 2015. Cecidophyopsis rosmarinusis Wang \& Elhalawany, 2014 was on Rosmarinus officinalis L. (Lamiaceae); Stenacis palomaris Keifer, 1970 was on Salix babylonica L. and S. matsudana Thunb (Salicaceae); Epitrimerus saudiarabis Wang \& Elhalawany, 2014 was on Phoenix dactylifera L. (Arecaceae); Epitrimerus cupressi Keifer, 1939 was on Cupressus sempervirens L. (Cupressaceae). The genera Cecidophyopsis and Stenacis are new records for Egyptian fauna. These species are vagrants on leaves without any damage except the second species (S. palomaris) which causes witches' broom of terminal twigs of the host plant. Illustrations of the four species are provided. Three phytoseiid mite species (i.e. Amblyseius swirskii Athias-Henriot, Cydnoseius negevi (Swirski \&Amitai), Typhlodromus (Typhlodromus) athiasae Porath \&Swirski (Acari: Phytoseiidae)), were found in association with the recorded eriophyid mites on the mentioned host plants during this survey.
\end{abstract}

Key words: Eriophyidae, Taxonomy, Cecidophyopsis, Epitrimerus, Stenacis, Phytoseiidae.

\section{INTRODUCTION}

A worldwide count of eriophyoid species is approximated to 4600 known species described under 420 genera (Amrine \& de Lillo unpublished databases $2003 \& 2010)$.

Genus Stenacis Keifer (1970) is characterized by body elongate-wormlike; opisthosoma with narrow annuli subequal dorsoventrally; prodorsal shield with narrow, basally hinged, anterior projection over gnathosoma, either apically blunt or emarginated or acute; scapular tubercles set little ahead of rear margin; directing scapular setae up and divergently ahead; gnathosoma moderately large; prodorsal shield sub semicircular in anterior outline; coxae with all three pairs of standard setae; legs with all standard setae; opisthosoma annulus entirely microtuberculate; female genitalia at a moderate distance behind rear coxae. Nine species of the genus Stenacis Keifer were reported (Amrine et al., 2003). Four of them were recoreded on Salicaceae, (i.e. Stenacis triradiatus Nalepa, 1892) on Salix alba L. from Bosnia, Czech Republic, Croatia, Finland. Germany, Herzegovina, Hungary, Iraq, Italy, Kyrgyz Republic, Mexico, Moldava, Serbia, Slovenia and USA; S. calisalicis Keifer, 1944 on S. babylonica L. from Italy and USA; S. palomaris Keifer, 1970 on S. lasiolepis Benth from Italy, Hungary and USA and $S$. lanzhouensis Kuang, 1997 on S. babylonica from China (de Lillo and Amrine 2011, unpublished data)). No records of Stenacis species infesting Cupressaceae are available up to date.

Cecidophyopsis Keifer, 1959, is characterized by, body wormlike, gnathosoma small, down curved, first visible segment longer than second; prodorsal shield broadly rounded anteriorly, not projecting over gnathosoma and concealing it in dorsal view; dorsal tubercles and setae missing; legs with all usual setae; opisthosoma annuli dorso-ventrally, microtuberculate; female genitalia close to coxae, the coxae separated somewhat; coxal tubercles, especially the second pair, partially surrounded by sub-circular elevations; female genital coverflap with numerous uneven longitudinal furrows, partly in two ranks. Up to date 19 species of the genus Cecidophyopsis Keifer are reported (Amrine et al. 2003). No species of this genus was reported from Egypt previously while two species were recorded from Saudi Arabia (i.e. Cecidophyopsis rosmarinusis Wang \& Elhalawany, 2014 on Rosmarinus officinalis L. (Lamiaceae) and Epitrimerus saudiarabis Wang \& Elhalawany, 2014 on Phoenix dactylifera L. (Arecaceae) Wang et al., 2014).

Seventy five eriophyoids belonging to 29 genera have been reported from Egypt. Among them, three belonging to the genus Epitrimerus, (Zaher, 1984, Elhalawany, 2012\& Elhalawany et al., 2015).

Occurrence of bio-agents in specific regions are essential task, as it can show the status of the bioagent/pests interactions, rising of new species or decline of dominant ones and the recovery of such fauna component after exposure to pesticides application. This action considers the first step to further studies about the use of bio-agents in biological control. Phytoseiid mites (Phytoseiidae: Mesostigmata) are predators of phytophagous mites and insects. Some species also feed on pollen and exudates from plants, but rarely plant tissue. Several members of this family are of great importance in the biological control of spider mites and other insect pests annoying crop production. Many researches dealt with the occurrence of phytoseiid mites in Egypt 
Ali (2006) and Azouz et al. (2011) (on fruit trees), Basha et al. 2001 (onvegetables) Hagrass et al. (2008) (on field crops), Romeih et al. (2010) (onaromatic and medical plants), El-Adawy et al. (2001), Metwally and Sanad (2005) and Metwally et al. 2013 (on non-cultivated plants).

The relation between phytoseiid and eriophyid mite species varies from occurrence together at the same host plant or in the galls caused by the eriophyids (Hajizadah et al., 2002, Prishmann et al., 2005 \& Lawson-Balagbo et al., 2008) to rich and fecund food source for the phytoseiids (Villanueva and Childers, 2007 and Momen (2009 a, b and 2014 ) and/or consider the phytoseiid mite species as a promising candidates to control the eriophyid mites (Brodeur et al., 1997, Metwally et al., 2005, LawsonBalagbo et al., 2007 and Fernando, 2009 ).

Survey of eriophyid fauna on Salix, Rosmarinus, Cupressus and Phoenix from Egypt was conducted. In addition, the associated phytoseiid mites to the same host plants during the course of the study were reported. The aim of this work was to elucidate on the Acari fauna of the mentioned host plants.

\section{MATERIALS AND METHODS}

During the three year period from 2012-2015, random samples of fruit trees, ornamental plants and weeds showing symptoms of mite infestation were carried out in Qalyubia and Giza governorates of
Egypt.

Eriophyid specimens were collected from plant samples by direct examination using a stereomicroscope. Eriophyids were slide mounted in Keifer's F-medium according to Amrine \& Manson (1996). The mites were examined and drawn using a Carl Zeiss phase-contrast microscope equipped with a drawing tube camera Lucida. Abbreviations follow Amrine et al. (2003). The morphological terminology used herein followed that of Lindquist (1996) and the generic classification based on Amrine et al. (2003). Specimens were measured following de Lillo et al. (2010). Host plant names and their synonymies were in accordance with the plant list on-line database (2010).

Phytoseiid mites were collected under a stereomicroscope or extracted from plant material using Berlese funnels. They were cleared in Nesbitt's fluid and slide mounted in Hoyer's medium. Their classification followed Chant and McMurtry (2007).

\section{RESULTS AND DISCUSSION}

New records for eriophyid mite fauna of Egypt.

Family: Eriophyidae Nalepa, 1898

Sub family: Cecidophyinae Keifer, 1966

Tribe: Cecidophyini Keifer, 1966

Cecidophyopsis rosmarinusis Wang \& Elhalawany, 2014 (Fig. 1)

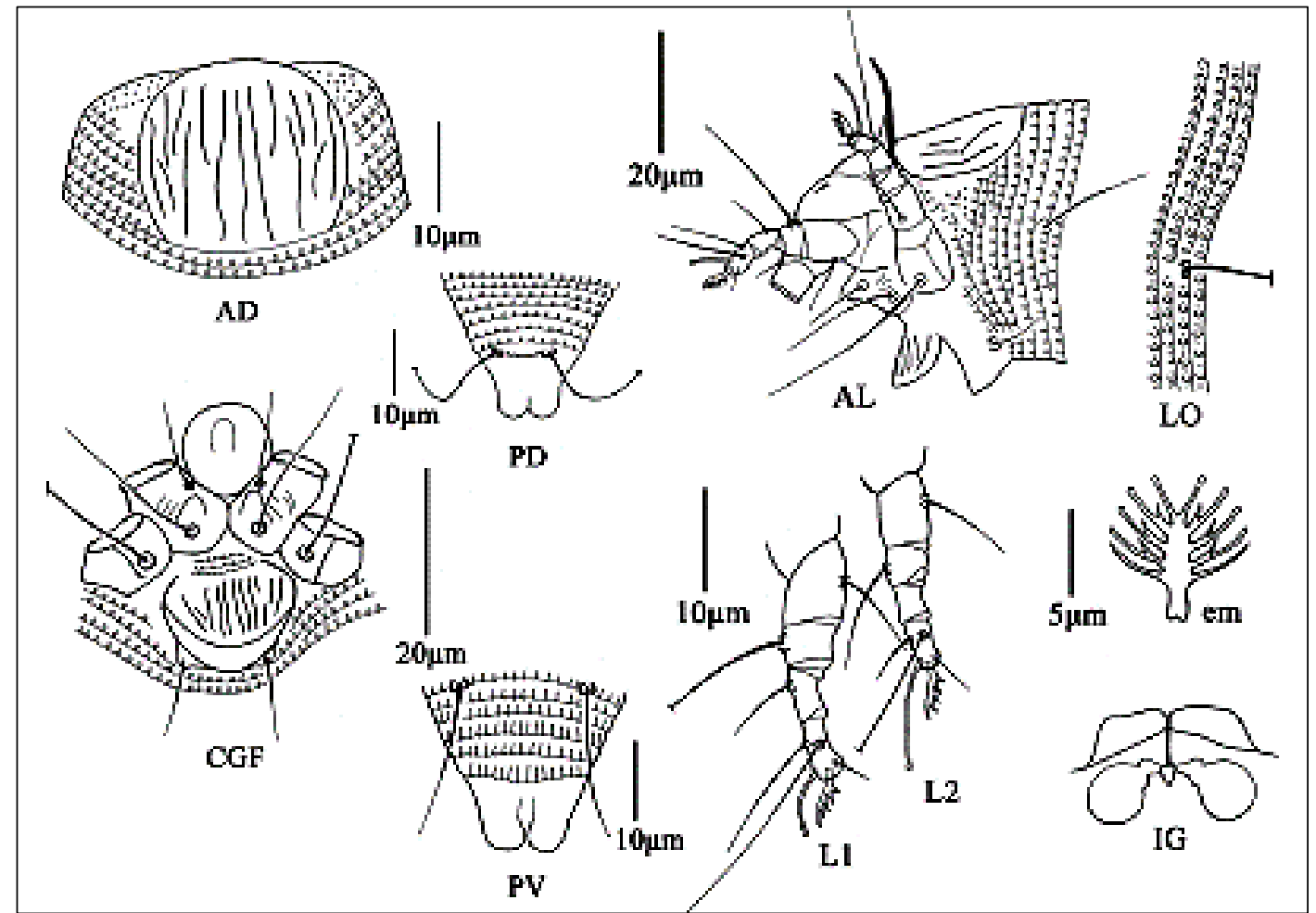

Fig. (1): Cecidophyopsis rosmarinusis Wang \& Elhalawany, 2014: AD, antero-dorsal view; AL, antero-lateral view of female; LO, microtubercles in lateral view; L1, Leg I; L2, leg II; em, empodium; IG, female internal genitalia; CGF, female coxae and genitalia; PD, postero-dorsal view; PV, postero-ventral view (drawing presented after Wang et al., 2014). 
Type data: Rosmarinus officinalis L. (Lamiaceae); Riyadh Province, Saudi Arabia.

Relation to the host plant: Vagrant on leaf surface. No damage to the host plant was observed. (Wang et al., 2014).

Geographic distribution: Saudi Arabia.

\section{Material examined:}

Two females on one slide (no. NJAUAcariEriEgypt6.4) from $R$. officinalis (Lamiaceae), Egypt, Giza, $30^{\circ} 1{ }^{\prime} 8 \mathrm{~N}, 31^{\circ} 12 \mathrm{E}, 15$ May 2013. Coll. A. Elhalawany; deposited as slide mounted specimens in the Arthropod/Mite Collection of the Department of Entomology, Nanjing Agricultural University, Jiangsu Province, China. Two slides, with the same data deposited at Department of Soil, Plant and Food Sciences (Di.S.S.P.A.), section of Entomology and Zoology,
University of Bari Aldo Moro, Bari, Italy. Four slides, with the same data deposited at Department of Zoology and Nematology, Faculty of Agricultural, Cairo University, Egypt. Ten females and three males on ten slides, with the same data (no. EGPErio32.132.10), 8 February 2015, deposited at fruit Acarology Department Plant Protection Research Institute Dokki Egypt.

\section{Remarks:}

This is the first record of occurrence of females and males of $C$. rosmarinusis in Egypt. The holotype female was described by Wang et al., 2014, the male not found. The morphometry of the female appears to match the original description by Wang et al., 2014.

Subfamily: Eriophyinae Nalepa, 1898

Tribe: Eriophyini Nalepa, 1898

Stenacis palomaris Keifer, 1970 (Fig. 2)

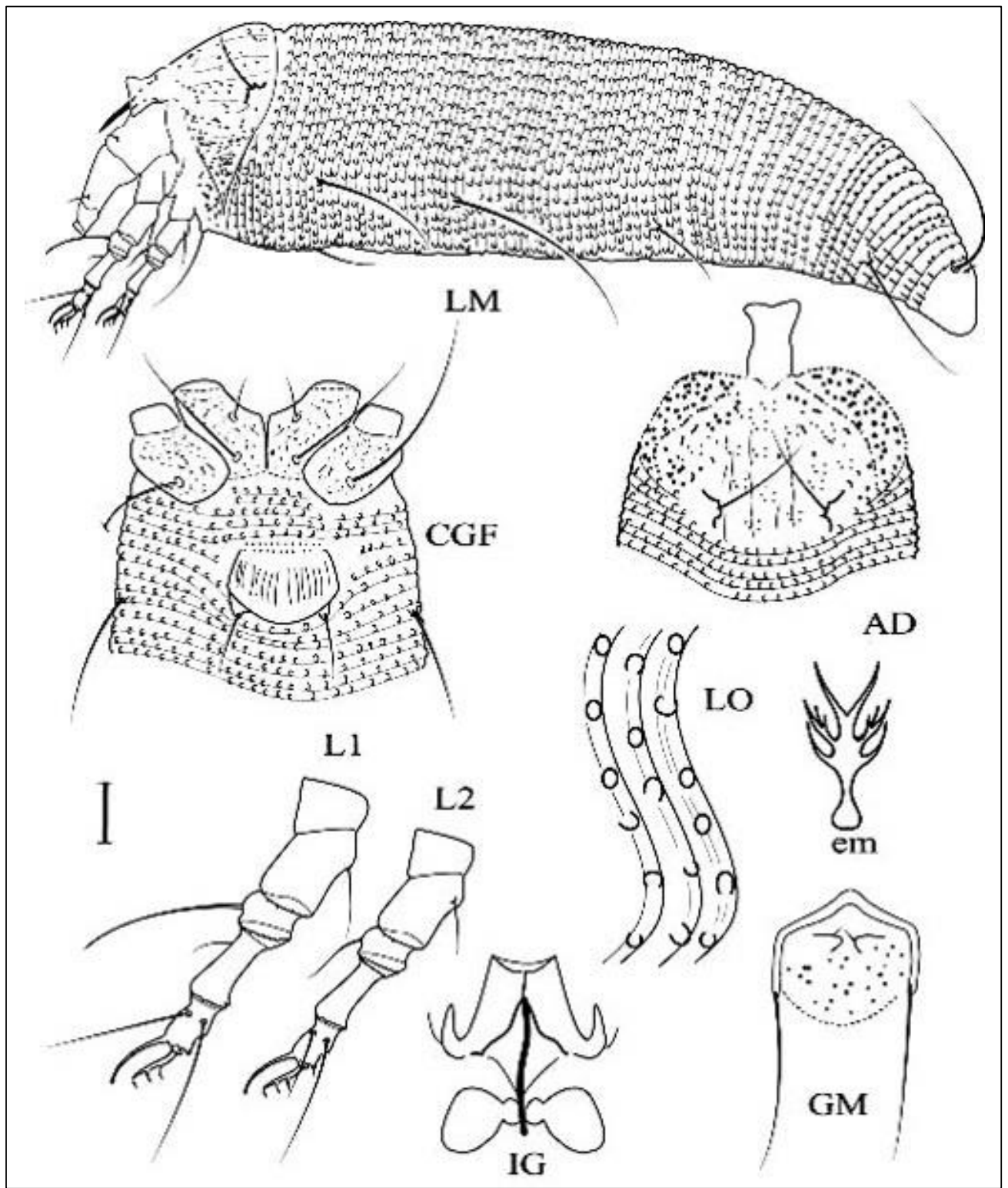

Fig. (2): Stenacis palomaris Keifer, 1970: LM, lateral view of female; AD, prodorsal shield female; CGF, female coxae and genitalia; em, empodium; LO, microtubercles in lateral view; L1, Leg I; L2, leg II; IG, female internal genitalia; GM, male genitalia. Scale bar- $10 \mu \mathrm{m}$ for LM , AD , CGF; $5 \mu \mathrm{m}$ for L1, L2, IG, GM; $2.5 \mu \mathrm{m}$ em $2.5 \mu \mathrm{m}$. (drawing presented after A. Elhalawany). 
Type data: Salix babylonica L., S. alba L., S. caprea L., S. elaeagnos Scop., S. matsudana Koidz, S. purpurea L. (Salicaceae).

Host plant from Egypt: S. babylonica L. and $S$. mucronata Thunb.

Relation to the host plant: The mites inhabit buds, petiole bases, and leaves on gall midge rosettes (Keifer, 1970). In Egypt, it causes witches' broom of terminal twigs of the host plant.

Distribution: Italy; Hungary and USA.

\section{Material examined:}

Four females and one male (slide no. NJAUAcariEriEgypt44.1-44.5), from S. babylonica, Qalyubia governorate, Egypt, 4 March 2012, $30^{\circ} 17^{\prime} 20^{\prime \prime} \mathrm{N} 31^{\circ} 12^{\prime} 46^{\prime \prime E}$ coll. A. Elhalawany, deposited as slide mounted specimens in the Arthropod/Mite Collection of the Department of Entomology, Nanjing Agricultural University, Jiangsu Province, China. 10 females and 10 males on 10 slides (slide no.EGPErio44.1-44.10), from $S$. mucronata, Qalyubia governorate, 10 May 2014, deposited at fruit Acarology Department Plant Protection Research Institute Dokki Egypt. 3 slides (no. AcY:13/372) with the same data deposited as slide mounted specimens in the National Collection of Arachnida, ARC-PPRI, Biosystematics, Pretoria South Africa. 4 slides, deposited at Department of Soil, Plant and Food Sciences (Di.S.S.P.A.), section of Entomology and Zoology, University of Bari Aldo Moro, Bari, Italy. Two slides, with the same data deposited at Department of Zoology and Nematology, Faculty of Agricultural, Cairo University, Egypt.

\section{Remarks:}

This is the first record of occurrence of females and males of Salix babylonica and S. mucronata in Egypt. The morphometry of the female appears to match the original description by Keifer, 1970. The principal differences between this species and the descriptions given by Keifer are the size of the specimens now examined is longest (190-220) long; opisthosoma annuli with (64-72); scapular seta $S c$ short (15-18) long and seta $3 a$ short (13-15) long, the Egyptian specimens are slightly longer than those in Keifer's description.

Sub family: Phyllocoptinae Nalepa, 1892

Tribe: Phyllocoptini Nalepa, 1892

Epitrimerus saudiarabis Wang\& Elhalawany, 2014 (Fig. 3)

\section{Synonyms:}

Acaphyllisa arabica Al-Atawi, Kamran \& Flechtmann, 2014.

Type data: Phoenix dactylifera L. (Arecaceae); Riyadh Province, Saudi Arabia, collected by the first author.
Relation to the host plant: Vagrant on inner leaf surface. No damage to the host plant was observed (Wang et al., 2014).

Geographic distribution. Saudi Arabia.

\section{Material examined:}

Five females and 2 males on 7 slides (no. AcY:13/368) from Egypt, Qalyubia, 30¹7'20.02"N, $31^{\circ} 14{ }^{\prime} 51.85^{\prime \prime} \mathrm{E} \quad 10$ October 2012. Coll. A. Elhalawany; deposited as slide mounted specimens in the National Collection of Arachnida, ARC-PPRI, Biosystematics, Pretoria South Africa. Two slides

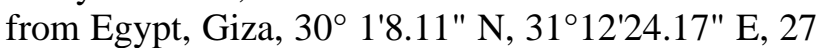
April 2014. Coll. A. Elhalawany, deposited at Department of Soil, Plant and Food Sciences (Di.S.S.P.A.), section of Entomology and Zoology, University of Bari Aldo Moro, Bari, Italy. 2 slides, with the same data deposited at Department of Zoology and Nematology, Faculty of Agricultural, Cairo University, Egypt.

\section{Remarks:}

The first author collected the same species from Riyadh province, Saudi Arabia during survey of mites inhabiting date palm. Al-atawi et al., 2014 published this species as Acaphyllisa arabica Al-Atawi, Kamran \& Flechtmann, 2014, depends on tarsal empodium divided into four rays on each side, while tarsal empodium 4-rayed simple, thus A. arabica is invalid name.

This is the first record of Epitrimerus saudiarabis Wang \& Elhalawany, 2014 from Egypt. The morphometry of the female and male appears to match the original description by Wang et al., 2014. Epitrimerus cupressi Keifer, 1939 (Fig. 4)

Platyphytoptus cupressi Keifer, 1939: 485-486.

Epitrimerus cupressi; Keifer, 1952: 54.

Epitrimerus cupressi; Amrine \& Stasny, 1994: 182.

Host plant: Cupressus sempervirens L. (Cupressaceae).

Relation to the host plant: Vagrants on tips of the twigs and squeezed into the crevices between the leaf scales.

\section{Distribution: USA.}

\section{Material examined:}

Four females and one male (slide number NJAUAcariEriEgypt23.1-23.5), from C. sempervirens, Qalyubia governorate, Egypt, 3 November $2012, \quad 30^{\circ} 15^{\prime} \mathrm{N}, \quad 31^{\circ} 13^{\prime} \mathrm{E}$, coll. A. Elhalawany, deposited as slide mounted specimens in the Arthropod/Mite Collection of the Department of Entomology, Nanjing Agricultural University, Jiangsu Province, China. 25 females and 10 males on 10 slides (slide no.EGPErio29.1-29.15), from C. sempervirens, Qalyubia governorate, Egypt, 3 November $2012, \quad 30^{\circ} 15^{\prime} \mathrm{N}, \quad 31^{\circ} 13^{\prime} \mathrm{E}, \quad$ coll. 


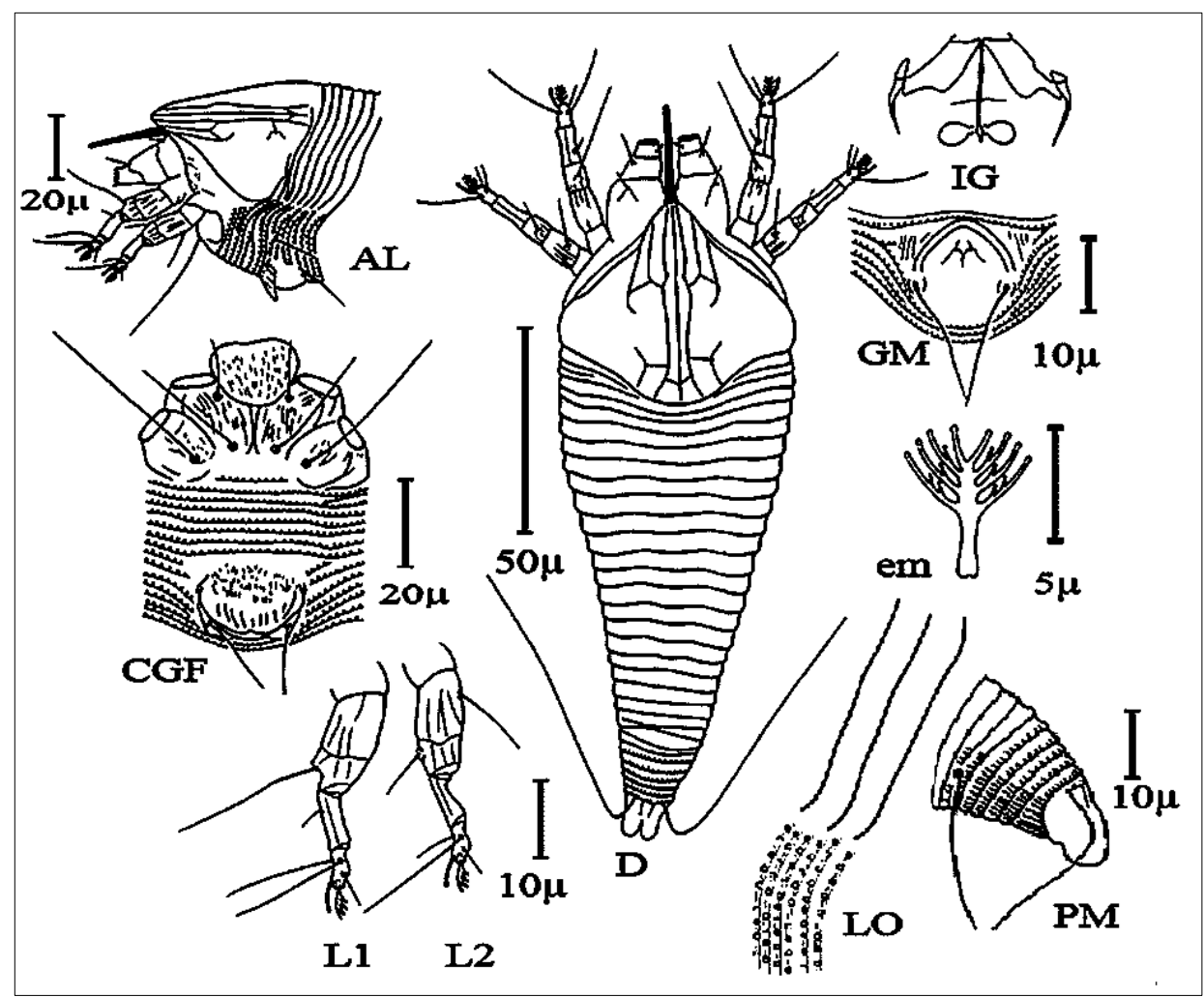

Fig. (3): Epitrimerus saudiarabis Wang\& Elhalawany, 2014: AL, antero-lateral view of female; D, dorsal view of female; IG, female internal genitalia; GM, male genitalia; em, empodium; CGF, female coxae and genitalia; LO, microtubercles in lateral view; PM, postero-lateral view of female; L1, Leg I; L2, leg II (drawing presented after Wang et al., 2014).

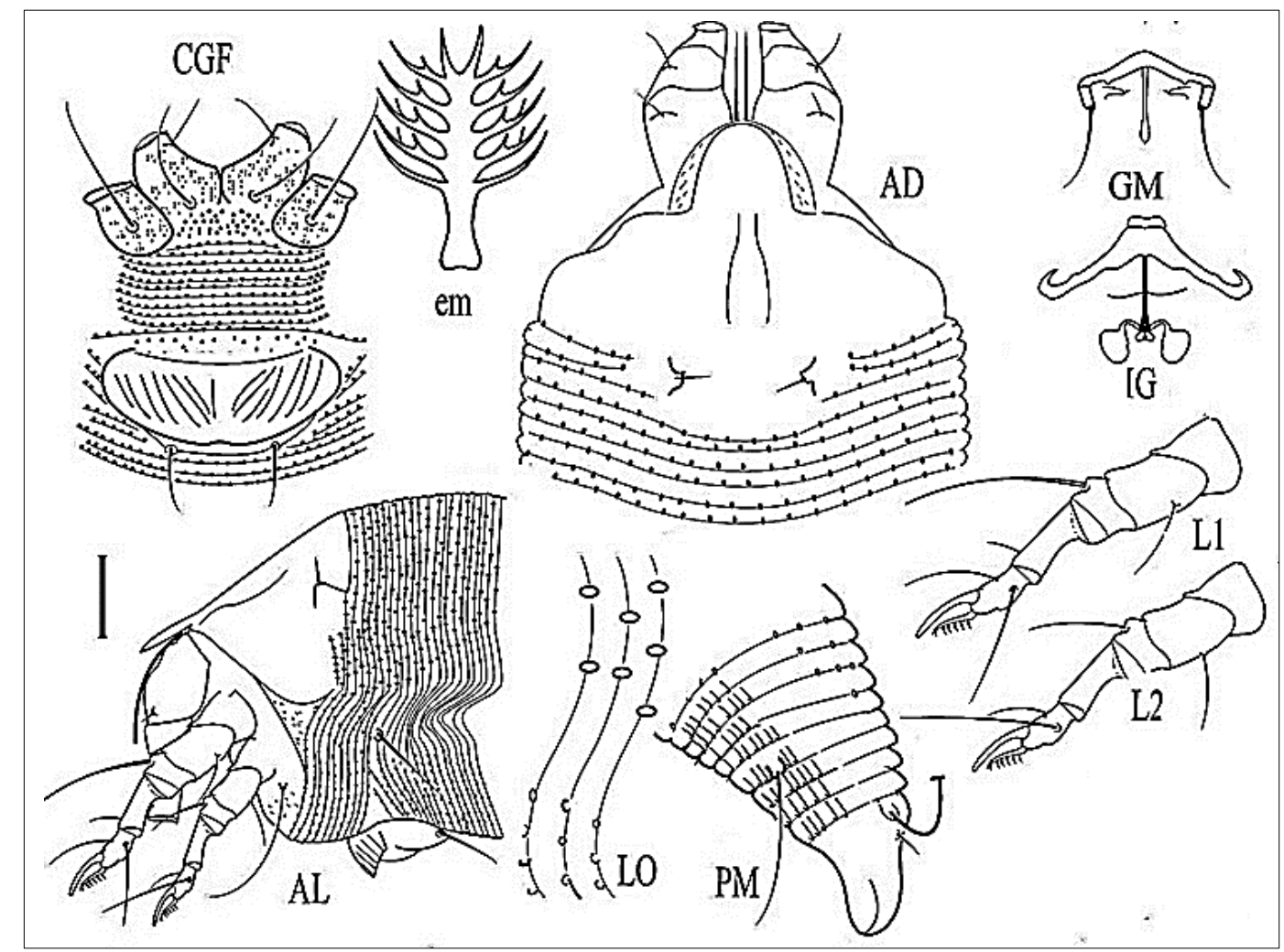

Fig. (4): Epitrimerus cupressi Keifer, 1939: AD, prodorsal shield female; em, empodium; CGF, female coxae and genitalia; AL, antero-lateral view of female; LO, microtubercles in lateral view; PM, postero-lateral view of female; L1, Leg I; L2, leg II; IG, female internal genitalia; GM, male genitalia. Scale bar- 10 $\mu$ m for all except em $2.5 \mu \mathrm{m}$. (drawing presented after A. Elhalawany). 
A. Elhalawany, deposited at fruit Acarology Department, Plant Protection Research Institute Dokki Egypt. Ten females and 5 males on 10 slides (slide no.EGPErio29.16-29.25), from $C$. sempervirens, Giza governorate, Egypt, 15 March $2014,30^{\circ} 1^{\prime} \mathrm{N}, 31^{\circ} 1^{\prime} \mathrm{E}$, coll. A. Elhalawany, deposited at fruit Acarology Department Plant Protection Research Institute Dokki Egypt; 2 slides with the same data, deposited at Department of Soil, Plant and Food Sciences (Di.S.S.P.A.), section of Entomology and Zoology, University of Bari Aldo Moro, Bari, Italy. Five slides, with the same data deposited at Department of Zoology and Nematology, Faculty of Agricultural, Cairo University, Egypt.

\section{Remarks:}

This is the first record of occurrence of females and males of E. cupressi in Egypt. The holotype female was described by Keifer 1939; the male not found. This species associated with Epitrimerus abousettai Elhalawany, Wang \& Xue, 2015 and Stenacis aegyptius Elhalawany, Wang \& Xue, 2015 (In press).

PHYTOSEIIDAE: Berlese

Subfamily: Amblyseiinae Muma

Tribe: Amblyseiini Muma

Subtribe: Amblyseiina Muma

Genus Amblyseius Berlese 1914: 143; Chant \& McMurtry 2007: 73.

Amblyseius swirskii Athias-Henriot

Amblyseius swirskii Athias-Henriot, 1962: 5; Porath \& Swirski, 1965: 95; Athias-Henriot, 1966: 195; Swirski et al., 1973: 80; Nasr \& Abou-Awad, 1985: 246; Kandeel \& Nassar, 1986: 174; Zaher, 1986: 105; Swirski et al., 1998: 103; Chant \& McMurtry, 2004: 199; 2007: 81; Ramadan et al., 2004: 191; Zannou et al., 2007: 27; Ramadan et al., 2009: 117; Ferragut et al., 2010: 124.

Amblyseius (Amblyseius) rykei Pritchard \& Baker, 1962: 249. (synonymy by Zannou et al., 2007: 27; Zannou \& Hanna, 2011: 339).

Amblyseius (Amblyseius) swirskii Ehara, 1966: 23.

Amblyseius enab El-Badry, 1967a: 178; 1970: 504; Nasr \& Abou-Awad, 1985: 246; Zaher, 1986: 104; Chant \& McMurtry, 2004: 199; 2007: 78. (synonymy by Ramadan et al., 2009: 117).

Typhlodromips enab Moraes et al., 1986: 140; 2004: 212.

Typhlodromips swirskii.-Moraes et al., 1986: 149; 2004: 227.

Amblyseius (Amblyseius) enab.-Ueckermann \& Loots, 1988: 73.

Typhlodromips capsicum Basha, Yousef, Ibrahim \& Mostafa, in Basha et al., 2001: 372 (new synonymy).
This mite species was found to associate with $C$. rosmarinusis on $R$. officinalis; $S$. palomaris on $S$. babylonica and S. matsudana; E. saudiarabis on $P$. dactylifera and E. cupressi on C. sempervirens. This predatory mite species has a wide range of host plant distribution (i. e. 22 host plants in Egypt) (Metwally et al., 2013).

Subfamily: Typhlodrominae Wainstein

Typhlodromini Wainstein, 1962a: 26.

Typhlodrominae Chant \& McMurtry, 1994: 235; 2007: 131.

Tribe Galendromimini Chant \& McMurtry 1994

Genus Cydnoseius Muma 1961

Cydnoseius negevi (Swirski \& Amitai) Galendromimini Chant \& McMurtry, 1994: 240; 2007: 137.

Typhlodromus (Typhlodromus) negevi Swirski \& Amitai, 1961: 194.

Typhlodromus negevi Amitai \& Swirski, 1966: 21.

Typhlodromus (Neoseiulus) negevi Ehara, 1966: 19. Cydnoseius cordiae Muma, 1967: 276. (synonymy by Chant \& Yoshida-Shaul, 1986b: 2815; Chant \& McMurtry, 1994: 241).

Typhlodromus medanicus El-Badry, 1967c: 108. (synonymy by Chant \& Yoshida-Shaul, 1986b: 2815; Chant \& McMurtry, 1994: 241).

Typhlodromus zaheri El-Badry, 1967a: 182. (synonymy by Chant \& Yoshida-Shaul, 1986b: 2815; Chant \& McMurtry, 1994: 241).

Typhlodromus zaheri El-Badry, 1970: 499; Zaher, 1986: 130. Typhlodromus africanus Yousef, 1980: 122. (synonymy by Chant \& Yoshida-Shaul, 1986b: 2815; Chant \& McMurtry, 1994: 241).

Typhlodromus schusteri Yousef \& El-Brollosy [sic], in Zaher (1986): 129. (synonymy by Kanouh et al., 2012: 266).

Cydnoseius africanus Moraes et al., 1986: 184; 2004: 263.

Typhlodromus cordiae Zaher, 1986: 128.

Cydnoseius cordiae Moraes et al., 1986: 184; 2004: 263.

Cydnoseius medanicus Moraes et al., 1986: 184; 2004: 263.

Cydnodromella negevi Chant \& Yoshida-Shaul, 1986b: 2815.

Amblydromella negevi Moraes et al., 1986: 168.

Cydnoseius zaheri Moraes et al., 1986: 184; 2004 . 263.

Cydnoseius negevi Swirski et al., 1998: 109; Chant \& McMurtry, 1994: 241; Moraes et al., 2004: 263; Negm et al., 2012b: 263.

Neoseiulella schusteri Moraes et al., 2004: 295.

This mite species was found to associate with $C$. rosmarinusis on $R$. officinalis ; S. palomaris on $S$. babylonica and $S$. matsudana; E. saudiarabis on 
$P$. dactylifera and $E$. cupressi on $C$. sempervirens. This predatory mite species has a moderate range of host plant distribution (i. e. Amaranthus sylvesris Desf., Cyperus alopecuroides Rottb., Setaria glauca L., Solanum melongena L. and Solanum nigrum L.) in Egypt. (Metwally et al. 2013).

Tribe: Typhlodromini Wainstein Typhlodromini Wainstein, 1962b: 26.

Genus: Typhlodromus (Typhlodromus) Scheuten Typhlodromus (Typhlodromus) athiasae Porath \& Swirski Chant, 1957: 289.

Typhlodromus athiasae Porath \& Swirski, 1965: 90; Swirski \& Amitai, 1965: 135; McMurtry, 1977: 22; Ragusa, 1977: 383; Swirski \& Ragusa; 1977: 78; Swirski \& Amitai,1985: 184; Moraes et al., 1986: 241; Zaher, 1986: 126; Çobanoğlu, 1989b: 172; Denmark, 1992b: 21; Swirski et al., 1998: 118.

Typhlodromus (Typhlodromus) athiasae-Ehara, 1966: 19; Moraes et al., 2004: 360; Papadoulis et al., 2009: 147; Barbar et al., 2013: 255.

Typhlodromus siwa El-Badry, 1967a: 183. (synonymy by Chant \& Yoshida-Shaul, 1987: 1791; Denmark, 1992b: 21).

Typhlodromus perbibus Wainstein \& Arutunjan, 1968: 1242. (synonymy by Chant \& Yoshida-Shaul, 1987: 1792; Denmark, 1992b: 21).

Typhlodromus pelargonicus El-Badry, 1968b: 142. (synonymy by Abbasova, 1972: 18; Chant \& Yoshida-Shaul, 1987: 1792; Denmark, 1992b: 21).

Typhlodromus hellenicus Swirski \& Ragusa, 1977: 75. (synonymy by Chant \& Yoshida-Shaul, 1987: 1792; Denmark, 1992b: 21).

Typhlodromus athiasae athiasae - Chant \& Yoshida-Shaul, 1987: 1791; Karg, 1989b: 279. Typhlodromus athiasae perbibus - Chant \& Yoshida-Shaul, 1987: 1792; Karg, 1989b: 279; 1991: 35; 1993: 218; Swirski et al., 1998: 118.

This mite species was found to associate with $C$. rosmarinusis on $R$. officinalis ; S. palomaris, on $S$. babylonica and $S$. matsudana. E. saudiarabis on $P$. dactylifera and $E$. cupressi on $C$. sempervirens. This predatory mite species was reported on (Convolvulus arvensis L. and Vitis vinifera L.) in Egypt (Metwally 2013).

Our results in agreement with those of LawsonBalagbo et al. (2007 and 2008) who reported the occurrence of Aceria guerreronis on coconut and Elhalawany (2012) who reported the association of 16 Eriophyid mite species to some fruit trees and with other investigations concerning with coexistence of the natural predatory mites with the Eriophyid mite species on the same host plant. Nine phytoseiid mite species were reported to be associated with Eriophyid mites in Iran (Hajizadeh et al., 2002), Neoseiulus hanselli was found inside willow galls (Salix sp.) caused by the eriophyid mite Aculus tetanothrix (Nalepa) (Prischmann et al., 2005)

The mentioned examples for the coexistence between the eriophyid and phytoseiid mites can explain the findings of our study; also open new prospects to further studies concerning the potentially application of the predatory mites and its involvement in the biocontrol of the eriophyid pests in the future specially for the economic plants.

\section{ACKNOWLEDGMENTS}

Deep thanks to Prof Dr. Enrico de Lillo University of Bari Aldo Moro, Italy for reviewing the earlier draft and suggestions on the manuscript. Appreciation to Prof Dr. M. Abou-Setta, PPRI-ARC, Egypt for reviewing the manuscript. Appreciation also to Dr. Gihan Sallam and Dr. Naglaa Fathi, for providing digital camera used in this study.

\section{REFERENCES}

Al-Atawi, F.; Kamran, M. and Flechtmann, C. H. 2014. Eriophyid mites (Prostigmata: Eriophyidea) associated with date palms: new record and a new species of the genus Acaphyllisa from Saudi Arabia. Internt. J Acarol., 40(4): 353-357.

Ali, M. 2006. Studies on some mite species infesting deciduous fruits in Upper Egypt. Ph. D. thesis Fac. Agric. Assiut Univ., 151 pp.

Amrine, J. W. and Manson, D. C. 1996. Preparation, mounting and descriptive study of eriophyid mites. In: Lindquist, E.E., Sabelis, M.W. \& Bruin J. (Eds.), Eriophyid mites: their biology, natural enemies and control. World Crop Pests, 6. Elsevier Science Publishing, Amsterdam, The Netherlands, pp. 383-396.

Amrine J. W. and Stasny T. A. 1994. Catalog of the Eriophyoidea (Acarina: Prostigmata) of the world. Indira Publish. House, West Bloomfield, Michigan, USA: 804 pp.

Amrine, J. W.; Stasny, T. A. and Flechtmann, C. H. 2003. Revised keys to the world genera of the Eriophyidea (Acari: Prostigmata). Indira Publishing House, West Bloomfield, Michigan, USA, 244 pp.

Azouz, H.; Khalil, A. and Abu Zaid, A. E. 2011. Survey of some mites and spiders associated with date palm at Beni-Suef governorate, Egypt. Egypt. J. Appl. Sci., 26: 50- 63.

Basha A. E.; Yousef, A. A.; Ibrahem, M. H. and Mostafa, E. M. 2001. Five new phytoseiids from Egypt (Acari: Gamasida: Phytoseiidae). Al-Azhar J. Agric. Res., 33: 371- 386.

Brodeur, J.; Bouchard, A. and Turcotte, G. 1997. 
Potential of four species of predatory mites as biological control agents of the tomato russet mite, Aculops lycopersici (Massee) (Eriophyidae). Can. Entomol., 129: 1-6.

Chant, D. A. and McMurtry, J. A. 2007. Illustrated keys and diagnoses for the genera and subgenera of the Phytoseiidae of the world (Acari: Mesostigmata). West Bloomfield (MI): Indira Publish. House; 220 pp.

de Lillo, E.; Craemer, C.; Amrine, J. W. and Nuzzaci, G. 2010. Recommended procedures and techniques for morphological studies of Eriophyidea (Acari: Prostigmata). Exp. Appl. Acarol., 51: 283-307.

Elhalawany, A. S. 2012. Survey of eriophyid mites on some fruit trees, with redescriptions of two newly recorded species and a checklist of eriophyid mites in Egypt (Acari: Eriophyidea). Egypt. Acad. J. biolog. Sci., 5(2): $205-216$.

Elhalawany, A. S.; Wang, Q. and Xue, X. F. 2015. Two new species of eriophyid mites (Acari: Eriophyidae) infesting Cupressus sempervirens from Egypt. Systematic and applied Acarology. (In press).

Fernando, L.C.; Waidyarathne, K. P.; Perera, K. F. and De Silva, P. H. 2009. Evidence for suppressing coconut mite, Aceria guerreronis by indative release of the predatory mite, Neoseiulus baraki. Biol Control. 53:108-111.

Hagrass, A. E.; EL-Naggar, M. E.; EL-Naggar, A. M. and Abou-Zeid, W. M. 2008. Incidence of mites inhabiting some field crops in two localities at Dakahlia governorate. Egypt. J. Agric. Res. 86: 353- 366.

Hajizadeh, J.; Hosseini, R. and McMurtry, J. A. 2002. Phytoseiid mites (Acari: Phytoseiidae) associated with eriophyid mites (Acari: Eriophyidae) in Guilan province of Iran. Intern. J. of Acarol., 28: 373-378.

Keifer H.H. 1939. Eriophyid Studies VII. Bulletin of the California Department of Agriculture, 28: 484505.

Keifer H.H. 1944. Eriophyid Studies XIV. Bulletin of the California Department of Agriculture, 33: 1838.

Keifer H.H. 1952. Eriophyid Studies XVIII. Bulletin of the California Department of Agriculture, 41: 31-42.

Keifer H.H. 1959. Eriophyid Studies XXVI. Bulletin of the California Department of Agriculture, 47: 271-281.

Keifer H.H. 1970. Eriophyid Studies C-4. Department of Agriculture, Agricultural Research Service, 24 pp.

Kuang, H.-Y and Pang, H.-L. 1997. Four new species of the Eriophyinae (Acari: Eriophyidae) from China. Entomotaxonomia, 19(3): 230-234.
Lawson, B. M. L; Gondim, J. M.; Moraes, G.; Hanna, R. and Schausberger, P. 2007. Life history of the predatory mites Neoseiulus paspalivorus and Proctolaelaps bickleyi, candidates for biological control of Aceria guerreronis. Exp. Appl. Acarol., 34: 49-61.

Lawson-Balagbo, L. M.; Gondim, J. M.; de Moraes, G. J.; Hanna, R. and Schausberger. P. 2008. Exploration of the acarine fauna on coconut palm in Brazil with emphasis on Aceria guerreronis (Acari: Eriophyidae) and its natural enemies. Bull. Entomol. Res., 98: 83-96.

Lindquist, E. E. 1996. External anatomy and notation of structures. In: Lindquist, E.E., Sabelis, M.W. \& Bruin, J. (Eds.), Eriophyid Mites: their biology, natural enemies and control. World Crop Pests, 6, Elsevier Science Publishing, Amsterdam, The Netherlands: $3-31$.

Metwally A. M. and Sanad, A.S. 2005. Description of the immature and adult stages of Neoseiulus arundonaxi n. sp. (Acari: Phytoseiidae) from Egypt. Bull. Ent. Soc. Egypt, 82: 63-70.

Metwally, A. M.; El Khateeb, H. M. and Sanad, A. S. 2013. Occurrence of some predaceous mites associated with plants free from chemical pesticides Egypt. J. Agric. Res., 91 (3): 949-958.

Nalepa A. 1892. New gall mites. (4 Fort.) Num. wharves. Akad. Wiss., Maths Nat. Kl., Vienna 29 (13): 128.

Prischmann, D. A.; James, D. G. and McMurtry, J. A. 2005. Occurrence of a predatory mite (Acari: Phytoseiidae) within willow galls caused by eriophyid mites. Intern. $\mathbf{J}$ Acarol, 31: 433-436.

Romeih, M. A., Hassan, M.; Rizk, M. A. and AboShnaf, R. A. 2010. Egyptian checklist of mites from aromatic, medicinal and ornamental plants. Acarines, 4: 37- 46.

Plant List 2010. Version 1. Published on the Internet. Available from: http://www.theplantlist.org/ (Accessed 29 May 2013).

Villanueva, R. T. and Childers, C. C. 2007. Development of Iphiseiodes quadripilis (Banks) (Acari: Phytoseiidae) on pollen or mites diets and predation on Aculops pelekassi (Keifer) (Acari: Eriophyidae) in the laboratory. Environ. Entomol., 36: 9-14.

Wang, Q.; Elhalawany, A. S.; Xue, X. F. and Hong, X. Y. 2014. New species and records of eriophyid mites from Saudi Arabia (Acari: Eriophyidea). Systematic and Applied Acarology. 19(4): 409430.

Zaher, M. A. 1984. Survey and ecological studies on phytophagous, predaceous and soil mites in Egypt. I: Phytophagous mites in Egypt (Nile valley and Delta). PI 480 Programme. USA Project No. EG. ARS, 30. Grant. No, FG, EG., 139. 228pp. 